\title{
THE MEN
}

00

Martin Dash, raised in Brooklyn, Yale graduate, member of the Dragons, married to Irene, served as an officer in the Naval Reserves on the destroyer USS McCormick in the Atlantic.

Harold Freeman, raised in Brooklyn, three years of college, antifascist, married to Bea, served as a rifleman in the 83 rd Infantry Division in the European Theater.

Victor Geller, born in the Bronx, Yeshiva-educated, second-generation Orthodox Jew of Hungarian parents, entered the military as a teenager, served as a rifleman in the 346 th Infantry Regiment in the European Theater.

Arthur Gorenstein, educated in Washington, D.C., high school graduate, socialist Zionist, served in the Army Air Corps, training as a Combat Engineer when the war ended.

Jeremiah Gutman, born in Brooklyn, CCNY graduate, served as a rifleman in the 69th Infantry Division in the European Theater.

RALPH JACKSON, born in Brooklyn, two years of college, member of the Dragons, married to Rita, served as a navigator/ bombardier in the 67th Bomb Squadron of the 8th Air Force based in England.

SY KAHN, born in Manhattan, high school graduate, served in the 495th Port Battalion of the Army Transportation Corps in New Guinea.

Ira Koplow, born and raised in Sioux Falls, South Dakota, second-generation Jew of Lithuanian parents, two years of col- 
lege, served in the Battalion Supply Office of the 1oth Armored Division in the European Theater.

Jerome Minkow, born in the Bronx, high school graduate, arrived in Manila as a replacement infantryman as peace was signed with the Japanese.

Merv Reines, raised in Patterson, New Jersey, and the Bronx, attended Penn State, married to Cheryl, served as a supply officer in the Marines in the Pacific Theater.

Howard SACHS, born in Brooklyn, educated in Hebraist elementary school, NYU graduate, served as a medic in the 71st Infantry Division in the European Theater.

Harold Saperstein, born and raised in Troy, New York, Cornell graduate, Reform rabbi of a congregation in Lynbrook, Long Island, pacifist and Zionist, married to Marcia with a son, served as a chaplain in the European Theater (Italy, France, Germany).

Akiva Skidell, born and educated in Grodno, Poland, college education in Toronto, emigrated to New York City, socialist Zionist activist, married to Ettie with a daughter, served as a radio operator in reconnaissance company in the 2nd Armored Division in the European Theater.

Paul Steinfeld, born and educated in the Bronx, graduate of CCNY and Teacher's Institute of Jewish Theological Seminary, Zionist, married to Lillian, served as a rifleman in the $95^{\text {th }}$ Infantry Division in the European Theater.

Herbert WALTERs, born in Brooklyn, college graduate, a lawyer, served in the 211th Anti-Aircraft Battalion in the Pacific Theater. 
GI JEWS 
